https://doi.org/10.5719/aub-g/68.1/9

\title{
THE PROMOTION OF PLOIEŞTI-VĂLENII DE MUNTE-BRAŞOV AXIS, A STEP TOWARDS A TERRITORIAL COHESION
}

\author{
ANCA-MIHAELA GHEORGHE (TOMA) ${ }^{1}$
}

\begin{abstract}
The purpose of the article is to highlight the tourist potential of Ploieşti-Vălenii de MunteBraşov axis, highlighting in the same time the characteristic problems of settlements located along this axis (in terms of quality of life, human capital).

Teleajen Valley was populated since ancient times. Testimony is the archaeological discoveries from: Bronze Age from the territory of towns: Gura Vitioarei (to which we add the Dacian citadels "Movila" and "Gorgonul"), Măneciu, Săcele; traces of Middle Paleolithic Era in the town Vălenii de Munte, traces of Neolithic Era, on the administrative territory of the current town Boldești-Scăieni. A suitable tourist promotion of this area, leads to an economically balanced development of the entire Prahova county. The quantitative data (statistical indicators) and qualitative data (information from European and national documents plus books and articles referring to the analyzed area) support the untapped potential of Ploieşti - Vălenii de Munte - Braşov Axis. The development of this way of access between Muntenia and Transylvania has gradually developed and the 12 towns analysed are dealing with problems regarding: the technical urbanistic equipment, the inadequate transport and travel infrastructure. The promotion of Prahova Valley has generated an agglomeration of investments in the Western and North-Western part of Prahova County and less in the Eastern and North-Eastern part (position of the axis shown).

Keywords: tourist attractions, human capital, infrastructure, quality of life, sustainable development.
\end{abstract}

\section{Introduction}

The territorial cohesion to which the entire European Union tends, involves the use of sustainable natural and anthropogenic resources, effective in removing dysfunction between localities, so that the natural and cultural framework is not to be damaged (Leipzig, 2007). The balanced development, functional diversification of towns and valorization of functional potential of towns are only a few of the strategic measures of the Romanian territorial system of settlements (SDTR, 2014).

1 University of Bucharest, Faculty of Geography, Doctoral School "Simion Mehedinţi", E-mail: gheorghe_anca_07@yahoo.com 
The term "axis" is highly debated by specialists in various fields. Four Romanian geographers in an article in 2009, support the presence of two structural axes: of national importance (characterized by: large number of inhabitants, intense economic activities) and structural axes of regional importance (complement the axes of national importance for a balance) (Peptenatu D. et al., 2009). A structural axis is defined by the presence of a circulating roadway that has the capacity to gather services, production entities and living spaces (Pintilii R.D., 2008).

The purpose of the article is to highlight the tourist potential of Ploieşti-Vălenii de Munte-Braşov axis, highlighting in the same time the characteristic problems of settlements located along this axis (in terms of quality of life, human capital).

Presently, Prahova County is strongly developed along National Road 1, and the Northeast (along National Road 1A) is left as a reserve, transit option when traffic jams are made on Prahova Valley. The purpose of this study is to bring to light the natural and anthropic potential of the Teleajen Valley in order to achieve the territorial cohesion of Prahova County.

Ploiești - Vălenii de Munte - Braşov Axis follows the direction of the National Road 1A (from Ploiești to the exit of Săcele town), crossing Valea Teleajenului (which has a particular picturesque nature, with both natural and anthropic tourist attractions) and crossing the Curvature Carpathians by Bretocea Pass, following the Valleys of Târlungului and Timișului (Fig. 1).

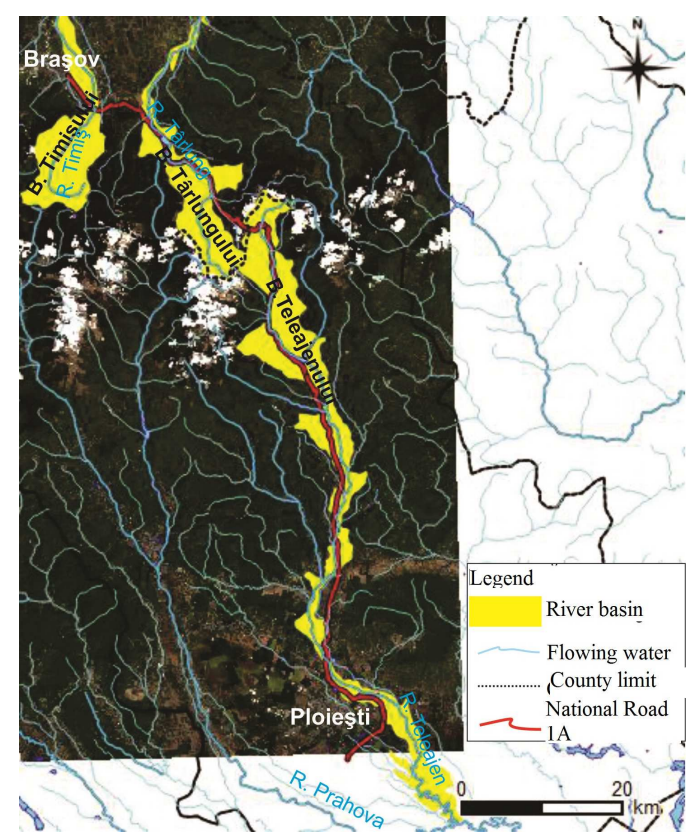

Fig. 1. Natural demarcation of Ploiești - Vălenii de Munte - Braşov Axis 
Teleajen Valley has the name of the omonym river (Teleajen River) which created it and is deployed in parallel with Prahova Valley. The name of this river comes from the use of the area as road of access to Transylvania, "the road to which you connect", used since ancient times, because it had a great economic importance for the people of Muntenia, facilitating the crossing of the mountain area.

The geographer Emm. de Martonne who introduced the notion of "subcarpathian depression" in the world, was impressed by the richness of the relief of these lands (Ielenicz M., Pătru I. Georgeta, Ghincea Mioara, 2003). The valleys of Văleni and Homorâciu with the fresco repositories and the Tarcău, Fusaru and Kliwa tiles are mentioned in the works: Professor Bocioacă Ioan, Popescu Paul (1988, Valeni de Munte, wonderful place of settlement), Niculescu Gh. and Velcea Ion (1973, Prahova County).

"The High Road of Teleajen" was crossed by travellers, carts with merchandise (by making external trade) and crossed the most important town since the $15^{\text {th }}$ century, the customs of Vălenii de Munte (fair since the $18^{\text {th }}$ century). From cartographic point of view, since the beginning of $19^{\text {th }}$ century, over the Teleajen Vally, 16 localities have developed (a fair and the rest villages) (Cruceru, 2011). Nowadays, there are 18 towns (4 urban and 14 rural) along Teleajen River, of which 5 urban settlements and 7 rural settlements are included in this study: Ploieşti, Boldeşti-Scăieni, Vălenii de Munte, Săcele, Braşov and respectively: Blejoi, Lipăneşti, Măgurele, Gura Vitioarei, Teişani, Izvoarele, Măneciu - Fig. 2.

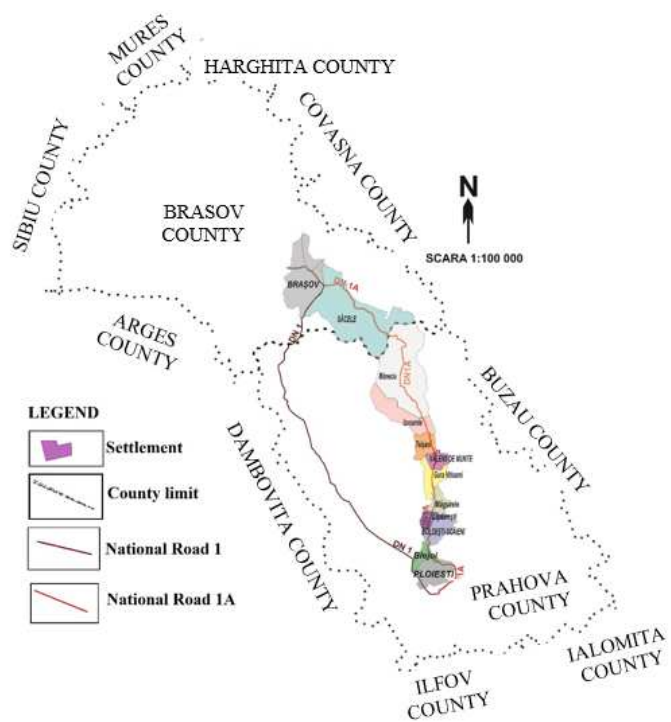

Fig. 2. Administrative demarcation of Ploieşti - Vălenii de Munte - Braşov Axis 


\section{Methodology}

The European and national documents such as: European Territory Arrangement Charter, Strategy for sustainable transportation for the period 2007-2013 and 2020, 2030 (European Territory Arrangement Charter, 1983), Regional Operational Programme 2014-2020, Strategy for sustainable transportation for the period 2007-2013 and 2020, 2030 (Sustainable Transportation Strategy, 2008), and many other websites, magazines and books from the geographyhistory field have been the starting point for this study. In Word and Excel we centralised all the data collected from the field travels, statistical data obtained from the National Institute of Statistics (INSSE), the Statistics Division of Prahova County and from the official website of the institute. They were all illustrated later in the study, under the form of charts, tables and maps (by using the software Excel, ENVI, QGIS and COREL).

The computation methods for the indicators used in the analysis are partly taken from the website of the National Institute of Statistics:

The population by residence on 1st July of each year for the period 19922017 (calculations made by the following formula and taken from the website of the institute):

$$
\mathrm{P}(\mathrm{t}+1)=\mathrm{P}(\mathrm{t})+\mathrm{N}(\mathrm{t}, \mathrm{t}+1)-\mathrm{D}(\mathrm{t}, \mathrm{t}+1)+\mathrm{dM}(\mathrm{t}, \mathrm{t}+1)+\mathrm{Cv}
$$

where:

$\mathrm{P}(\mathrm{t}+1)$ - population with residence in the country at the moment $t+1$;

$\mathrm{P}(\mathrm{t})$ - population with residence in the country at moment $\mathrm{t}$;

$N(t, t+1)$ - number of living newborns during the period ( $t, t+1)$, whose mother had residence in Romania at the date of birth;

$D(t, t+1)$ - number of persons who died during the period $(t, t+1)$, who had residence in Romania at death date;

$\mathrm{dM}(\mathrm{t}, \mathrm{t}+1)$ - final international migration numbers (immigrants -

emigrants), for the period $(t, t+1)$;

Cv - age adjustment coefficient (Institutul Naţional de Statistică, 2018)

Tourist reception structure with functions of tourism accommodation for the year 2017, taken from the website of the National Institute of Statistics (Fig. 3). 
THE PROMOTION OF PLOIEŞTI-VĂLENII DE MUNTE-BRAŞOV AXIS,

Density of habitation by life environments, rural and urban, during the period 1992-2017 (Fig.7):

$$
\begin{gathered}
\mathrm{D}_{\text {habitation of rural environment }}(\mathrm{t})=\Sigma\left(\mathrm{S}_{\text {habitable } \mathrm{X}}(\mathrm{t}) / \mathrm{P}_{\text {total X}}(\mathrm{t})\right) \\
\mathrm{D}_{\text {habitation of urban environment }}=\Sigma\left(\mathrm{S}_{\text {habitable X }}(\mathrm{t}) / \mathrm{P}_{\text {total } X}(\mathrm{t})\right)
\end{gathered}
$$

where:

$D_{\text {habitation of rural environment }}(t)$ - density of habitation for villages „X” in the year ,"t"

$\mathrm{D}_{\text {habitation of urban environment }}(\mathrm{t})$ - density of habitation for urban towns „X” in the year ,t”,

$\mathrm{t}-$ year

$S_{\text {habitable }}(t)$ - The (total) deployed habitable area (surface) (aria) represents the sum of areas designed for housing of all houses or habitable spaces in buildings at town level in each year " $\mathrm{t}$ " of the period 1992-2017

$\mathrm{P}_{\text {total }}(\mathrm{t})$ - Population by residence on 1st July of each year " $\mathrm{t}$ " for the period 1992-2017, for each town"X".

The houses that existed at analysed town level, at the end of each year of the period 1992-2017 - the housing fund was determined based on the data obtained at the census of population and houses taking into account the changes occurred during each year (number of constructions of houses and demolitions or change of destinations of houses) (Fig.8);

The natural growth per thousand inhabitants by life environments (rural and urban) for the period 1992-2017 (Fig. 9)

$$
\begin{gathered}
\operatorname{RS}_{\text {rural }}(t)=R_{\text {rural natality }}(t)-R_{\text {rural mortality }}(t) \\
\operatorname{RSurban}(t)=R_{\text {urban natality }}(t)-R_{\text {urban mortality }}(t)
\end{gathered}
$$

where:

$\mathrm{RS}_{\text {rural }}(\mathrm{t}), \mathrm{RS}_{\text {urban }}(\mathrm{t})$ - natural growth per thousand inhabitants from rural and urban environments for each year ,t" of the period 1992-2017 
$\mathrm{R}_{\text {rural/urban natality }}(\mathrm{t})$ - birth rate per thousand inhabitants in the year „t" (number of living newborns compared to total population and multiplied by 1000)

$\mathrm{R}_{\text {rural/urban mortality }}(\mathrm{t})$ - death rate per thousand inhabitants in the year ,t" (number of deaths compared to total population and multiplied by 1000)

The length of water and gases distribution networks and of the sewage pipes compared for the years 1992 and 2017 was taken from the website of the National Institute of Statistics and illustrated by charts (Fig. 10, Fig. 11, Fig. 12).

The activity rate at the Censuses of Houses and Population for the years 2002 and 2011 (Fig. 13):

$$
\mathrm{Ra}_{\text {town }}(\mathrm{t})=\mathrm{Pa} \mathrm{a}_{\text {town }}(\mathrm{t}) /\left(\mathrm{Pa} \text { town }(\mathrm{t})+\mathrm{Pi}_{\text {town }}(\mathrm{t})\right)^{* 100}
$$

where:

$\mathrm{Ra}_{\text {town }}(\mathrm{t})$ - activity rate at town level in the year" $\mathrm{t}$ "

$\mathrm{Pa}_{\text {town }}(\mathrm{t})$ - active population at town level in the year " $\mathrm{t}$ "

$\mathrm{Pi}_{\text {town }}(\mathrm{t})$ - inactive population at town level in the year $\mathrm{t}$ "

$\mathrm{t}$ - reference year 2002 or 2011

For example:

$$
\begin{aligned}
\operatorname{Ra}_{\text {Braşov }} & =\operatorname{Pa}_{\text {Braşov }}(2011) /\left(\operatorname{Pa}_{\text {Braşov }}(2011)+\mathrm{Pi}_{\text {Braşov }}(2011)\right) * 100 \\
& =123370 /(123370+129830) * 100=48,72 \%
\end{aligned}
$$

The occupied population by sectors of activity at the level of Censuses of Houses and Population of 2002 and 2011 (Fig. 14), calculated from the data obtained from the National Institute of Statistics

$$
\mathrm{Po}_{\text {primary/secondary/tertiary sector }} \text { commune }(\mathrm{t})=\mathrm{P}_{\text {primary } / \text { secondary } / \text { tertiary }}(\mathrm{t}) / \mathrm{Po}(\mathrm{t})
$$

where:

$\mathrm{Po}_{\text {primary/secondary/tertiary sector }}$ commune $(\mathrm{t})$ - population occupied by branches of activity, primary, secondary and tertiary, at commune level, in the year " $\mathrm{t}$ "

$\operatorname{Po}(\mathrm{t})$ - total occupied population in a commune in the year " $\mathrm{t}$ " 
$\mathrm{P}_{\text {primary/secondary/tertiary }}(\mathrm{t})$ - population occupied in one of the activity sectors in a commune in the year " $\mathrm{t}$ "

For example:

$\mathrm{Po}_{\text {primary }}$ Izvoarele $(2011)=959 / 2565 * 100=37.39 \%$

Primary sector - occupied population in agriculture, forestry and fish farming

Secondary sector - occupied population in industry and constructions

Tertiary sector - occupied population in the fields of transportation, storage and communications, commerce, public administration and defence, social insurances, education, health and other

\section{Results and discussions}

The oldest town from Ploiești - Vălenii de Munte - Brașov Axis is the city Braşov, which was recorded since the beginning of the $13^{\text {th }}$ century and shortly became the most important town of Bârsei Depression. The historical sources mentioned the town Săcele in 1366, which became municipality in 1482. The same century is important also for Vălenii de Munte (which became the county seat of Saac county at the end of the 16th century (Bocioacă I., 2004).

The town Ploiești was founded by the Prince Mihai Viteazul in 1599 on the basis of the existing village ("On October 15, 1599 Mihai Viteazul started at the head of the main group in Ploiesti, passed the Carpathians through Tabla Butii Pass and reached Prejmer on October 17, 1599 and then conquers Brasov" (Petrescu C.I., 2006, p. 46). The 15th century represented the moment of appearance of the towns Izvoarele, Mănciu, Blejoi from Teleajen Valley. A century later, four towns were founded: Teișani (1529), Lipănești (1597 - former town Frijureni), Boldești-Scăieni (since 1503 Boldești and since 1581 Scăieni), Măgurele (SDL Magurele, 2015). The settlement Gura Vitioarei was attested by documents since the $17^{\text {th }}$ century (SDD Gura Vitioarei, 2014).

The end of $18^{\text {th }}$ century brought administrative changes and not only: new villages appeared (Suzana - near the omonym monastery, Gheaba, MăneciuUngureni - from the Romanians who came from Transylvania, Tabaci - with craftsmen in leather processing), on one part of Frijureni estate the Schitul Zamfira (Zamfira Convent) was built (1720), the rich salt ores of Teișani led to the development of the whole county, Ploiești became a manufacturing and commercial centre, Brașov had washhouses, wool, cotton, silk processing factories, etc. (Cruceru, 2011). 
The following two centuries represented the prolific age of Teleajen Valley: the Saac county was dissolved in favour of Prahova County which assimilated Teleajenului mountainous region, Braşov and Ploiești became railway nodes and moreover the connection road was reconstructed (1846). All this led to a serious development from economic and demographic point of view (the refineries of Ploiești processed over $80 \%$ of the oil in Romania) (Local Agenda 21, 2002). After 1968 the configurations of the current communes were completed: Common Blejoi (with 3 component villages), Common Lipanesti (with 4 component villages), Common Magurele (with 3 component villages), Common Gura Vitioarei (with 5 component villages), Common Teisani (with 5 component villages), Common Izvoarele (with 6 component villages) and Common Maneciu (with 9 component villages). (Law no. 351, 2001) (Law no. 100, 2007)

The human being is capable to achieve a sustainable development of a space by analysing the natural framework with favourable and restrictive points. Time has proven it with the analysed area, by offering today an oicumenic space composed of three municipalities (Braşov, Săcele and Ploieşti) of which two are county seats, two towns (Boldeşti - Scăieni and Vălenii de Munte), seven communes with thirty-five villages.

The present dysfunctions in the area mentioned are: inadequacy of transportation and tourist infrastructure, quality of habitation at minimal standards in certain areas, negative natural growth, defective collaboration between centres and towns, large difference of inhabitants between county seats and the other towns, single-specialisation of villages.

\section{Inadequacy of transportation and tourist infrastructure in the analysed area}

Nowadays the National Road 1A, which coincides with Ploieşti - Vălenii de Munte - Braşov Axis, on the section Ploieşti-Braşov, has only one lane by direction, except for the town of Vălenii de Munte where there is a portion in the central area where two lanes by one direction are arranged. This national route is crossed by many county roads (for example: County Road 102 PloieştiIzvoarele, County Road 103A Braşov - Zizin, County Road 219 Teişani-Predeal Sărari etc.) and many communal roads. Less than half of these roads are in very good and good condition; the communal roads are mainly in mediocre or bad condition (PDDJ Prahova, 2013).

As for the public transportation of persons, there are 20 regular routes which cross the towns of Prahova County and 3 routes which cross the two municipalities of Brașov County.

The railway transportation is very well-represented in the county seats Ploieşti and Braşov, which are major traffic nodes, and the towns of Prahova 
county have private railway transport since 2014, Transferoviar Călători on the former railway Ploieşti-Măneciu (Transferoviar Călători, 2018).

The air transportation is in the stage of project in the Municipality of Braşov, will be completed in 2020, which would attract many investors.

The little valorisation of the north-eastern and eastern part of Prahova county is due to the economic policies applied, channeling most of investments on Prahova Valley and offering Teleajen Valley only the title of road alternative in week-end for the car drivers (when the traffic is stuck on Prahova Valley) and especially for the transport of merchandise during the hours 6:00-22:00 from Monday to Friday and on legal holidays, when the National Road 1 is accessible only to those who obtained a passage licence. Even if in the county plans there are provisions regarding the decongestioning of traffic on both routes (DN1 and DN1A) we emphasize the obtention of funds and approvals for the finalisation of Bucharest-Brașov Highway.

The historical roads ("Drumul vinului" ("Wine Road") and "Drumul Fructelor" ("Fruit Road") together with the landscapes of Teleajen Valley are worth being valorised for tourists, because they are crowned with tourist attractions: Vălenii de Munte tourist resort, "The Nature of the upper Teleajenului Valley" Museum, Cheia Monastery, Suzana Monastery, Zamfira Monastery, and others. (PUG Lipăneşti, 2008) More than 30 religious objectives are located on the Ploiești - Valenii de Munte - Brasov Axis and 25 civil objectives (National Colleges, Ploieşti Culture Palace and other old buildings with a special architecture), according to PATN 2009 (Fig. 3).

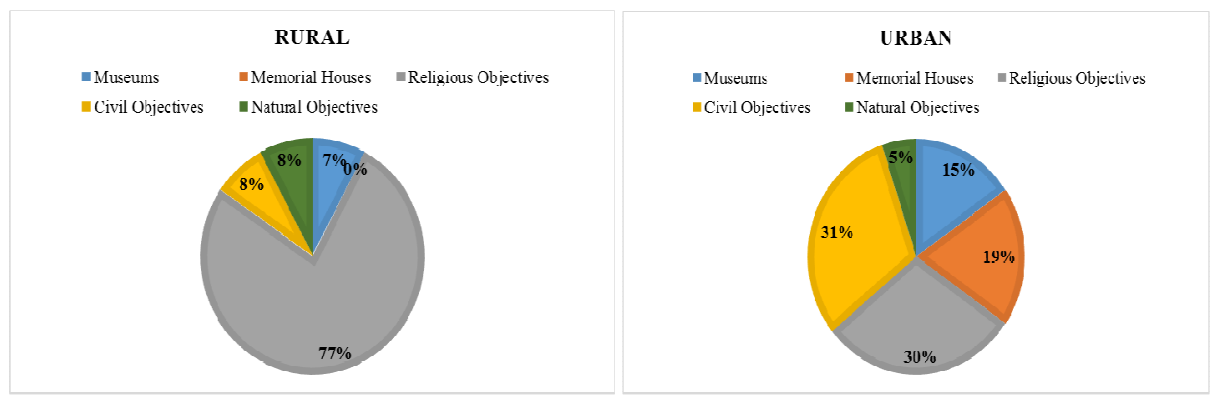

Fig.3. The share of tourism resources by categories on rural and urban level through the Ploiesti - Vălenii de Munte - Braşov Axis Source: PATN Section VI - Tourist areas, 2009

Nowadays the recreational and itinerant tourism is promoted, there are 3 motels, 84 hotels, 23 tourist villas, 5 chalets and 109 tourist boarding houses and 26 agrotourist boarding houses, mainly concentrated in the cities (Fig. 4). 


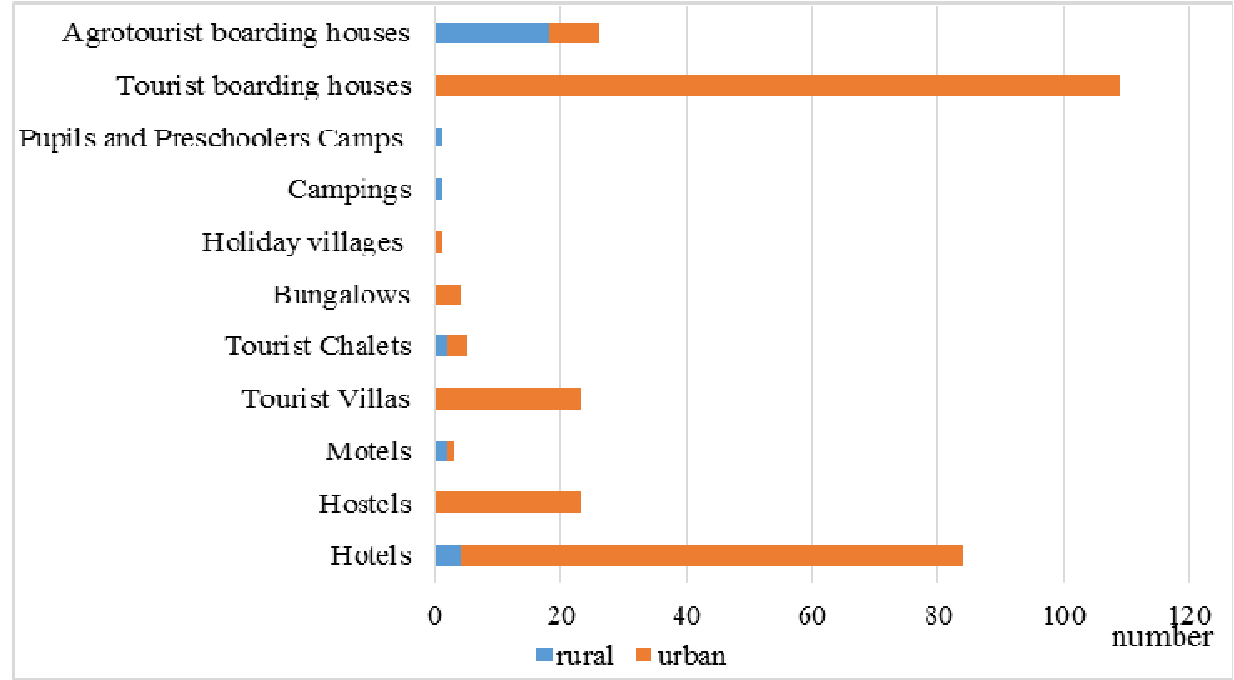

Fig.4. Current lodging units along Ploieşti - Vălenii de Munte - Braşov Axis (2017) Source of data: National Institute of Statistics, 21 November 2018

Only in Poiana Braşov there is cable railway infrastructure, ski slopes arranged by degrees of difficulty, in Cheia Resort the ski slope Babescu is at project level (equipped with carriage back, related spaces, access road etc.) (http://www.brasovcity.ro/index.php?ck=17; 2016). I consider the sightseeing points, diversification of tourist services as important measures for the development of this axis.

\section{Quality of habitation in the analysed area}

The population of a region promotes the local economy, supports the social development, being closely influenced by the natural framework (altitude, resources etc.) (Erdeli, Dumitrache, 2001).

Ploieşti - Vălenii de Munte - Braşov Axis crosses the Curvature Carpathians, concentrating twelve towns: five urban towns (Ploieşti, Boldești-Scăieni, Vălenii de Munte, Săcele and Braşov) and seven villages (Blejoi, Lipăneşti, Măgurele, Gura Vitioarei, Teişani, Izvoarele and Măneciu). In this demographic analysis I will present the situations by life environments or at general level and less by each settlement, for comprehensive reasons). However, I mention the large difference of inhabitants between the county seat and the other towns (Fig. 5); the cause is the multitude of services and jobs offered by the urban centres Ploieşti and Braşov. 


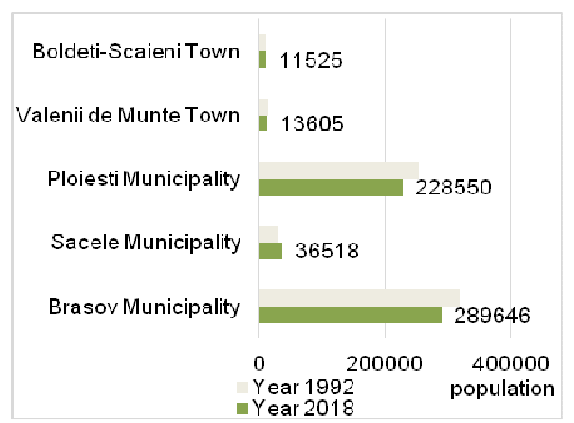

Fig. 5. Large difference of inhabitants between the urban centres Ploieşti and Braşov and the other towns in the area

Source of data: INS, Tempo on line data base

The ascending trend until 1995 and descending trend of today of the number of inhabitants in the 12 towns characterise the whole country (Fig. 6). The main causes of this evolution are: the pronatalist policies until 1989, gradual modernisation of society has encouraged the involvement of women in professional life. Thus, while in the year 1992 there were 673.778 persons (628.219 persons in the urban environment and 45559 persons in the rural environment), in the year 2018 there are 625.452 persons (579.844 inhabitants in the urban environment and 45.608 in the rural environment).

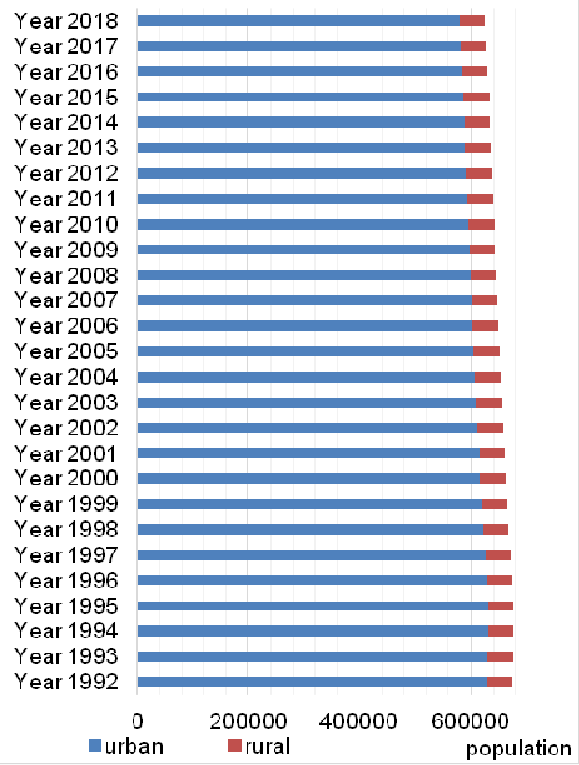

Fig. 6. Evolution of the number of inhabitants in Ploieşti - Vălenii de Munte - Braşov Axis for the period 1992-2018 Source of data: INS, Tempo on line data base 
The utility, beauty and solidity of a house represented the concerns of people since ancient times. The expression "quality of habitation" designates many components (indicators of urban development and spatial-urbanistic indicators, structure of building and its relationship with the neighbourhood (Nae, 2006), but in this analysis we present in detail the density of habitation and urbanistic infrastructure.

The crowdedness degree in a house, the habitable area/inhabitant suggest the degree of comfort offered by the house.

During the period 1992-2017 in the area under study, we can see that both life environments (urban and rural) doubled this indicator in the last two decades and a half (in urban environment from $11.17 \mathrm{~m}^{2} /$ inhabitant in 1992 to $19.61 \mathrm{~m}^{2} /$ inhabitant in 2017; in rural environment it went from $9.63 \mathrm{~m}^{2} /$ inhabitant in 1992 and got to $22.09 \mathrm{~m}^{2} /$ inhabitant in 2017) (Fig. 7).

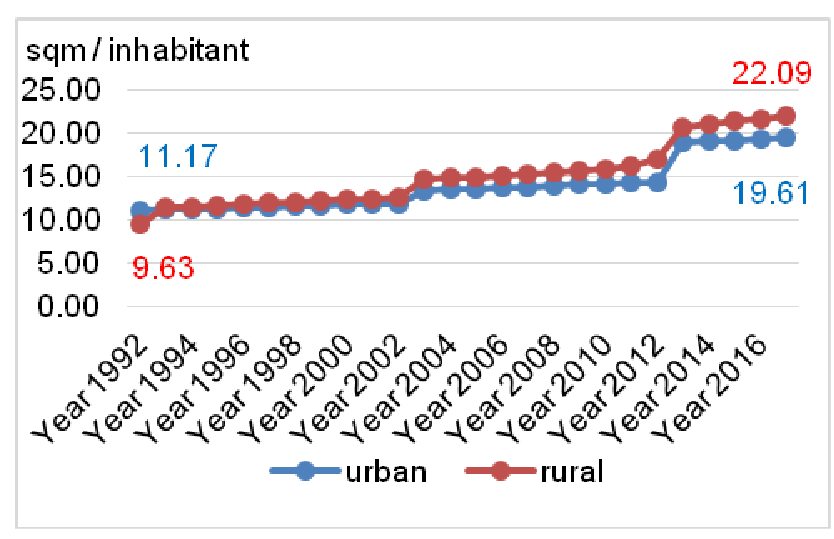

Fig. 7. Evolution of habitation density for the area under study, during the period 1992-2017, for the two life environments Source of data: calculated after Tempo on line data base

The increase in living conditions, the increase in the number of constructions (Fig. 8) and the negative natural growth (Fig. 9) are the main elements which led to this evolution of the habitation density. In the next chart you can see that all the analysed towns have recorded increases in the number of houses from the end of the year 1992 until 2017. The most significant values were recorded in the urban environment and in the towns from the vicinity, the phenomenon of gentrification, modernisation of current society has appeared. 


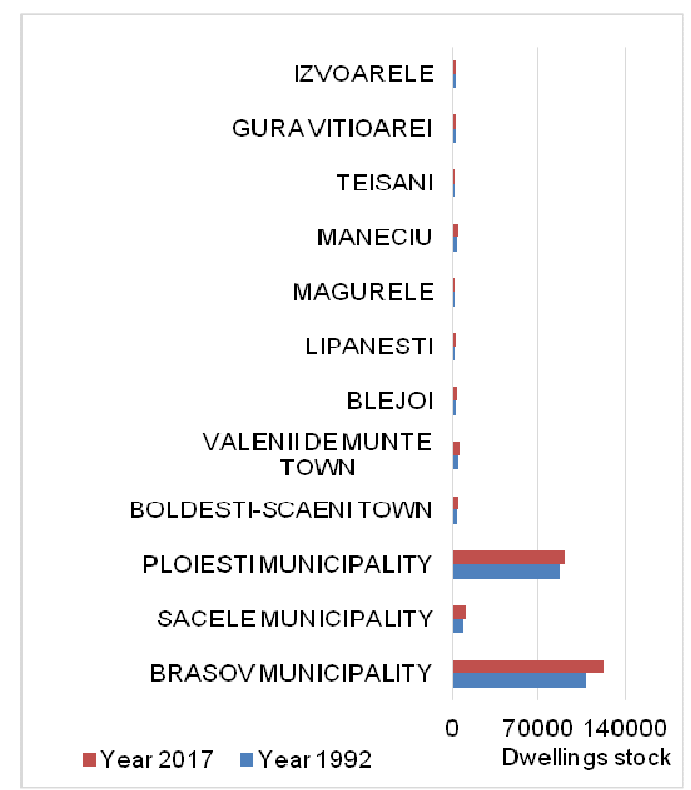

Fig. 8. Houses that existed at the end of years 1992 and 2017 in the analysed area

Source of data: calculated after Tempo on line data base

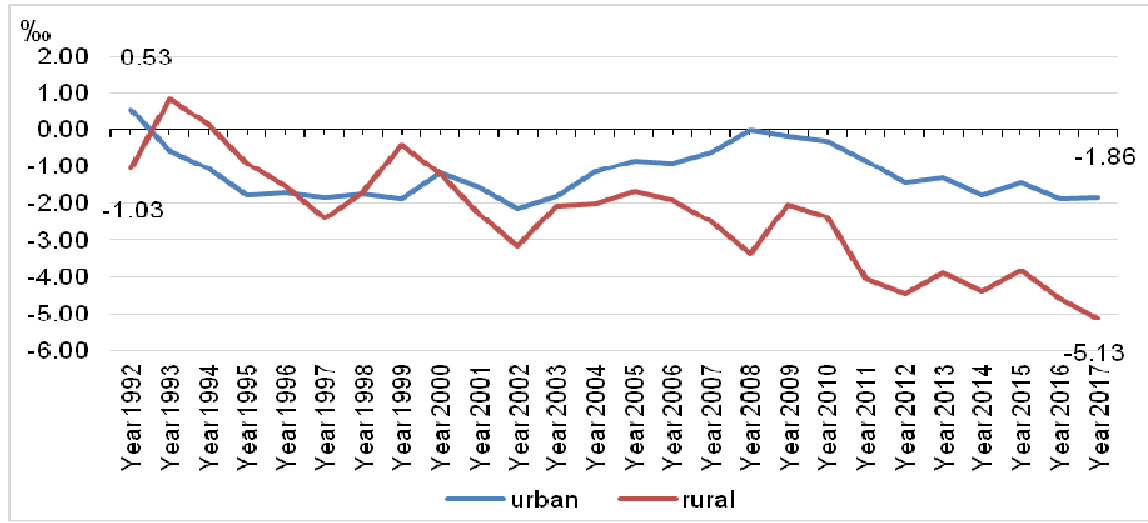

Fig. 9. Natural growth in the urban and rural environments in the area of Ploieşti - Vălenii de Munte - Braşov Axis (1992-2017) Source of data: INS, Tempo on line data base

Both in the urban and rural environments, since 1993 the natural growth has been negative with a more pronounced value in the rural environment $(-1,03 \%$ o in 1992 to $-5,13 \%$ in 2017) because of pronatalist policies that were not supported after 1990, a frequently encountered phenomenon in modern Romania, the rural 
demographic ageing, the end of industrialisation has represented another cause for the leaving of youth for the big cities (Fig. 9).

Before 1990, the municipalities and towns benefited from gas, water, sewerage networks, but in the rural area of the analysed space the urban technical equipment has gradually penetrated with difficulty (since 1999 the potable water supply network has been installed, and has increased in length every year) (Fig. 10).

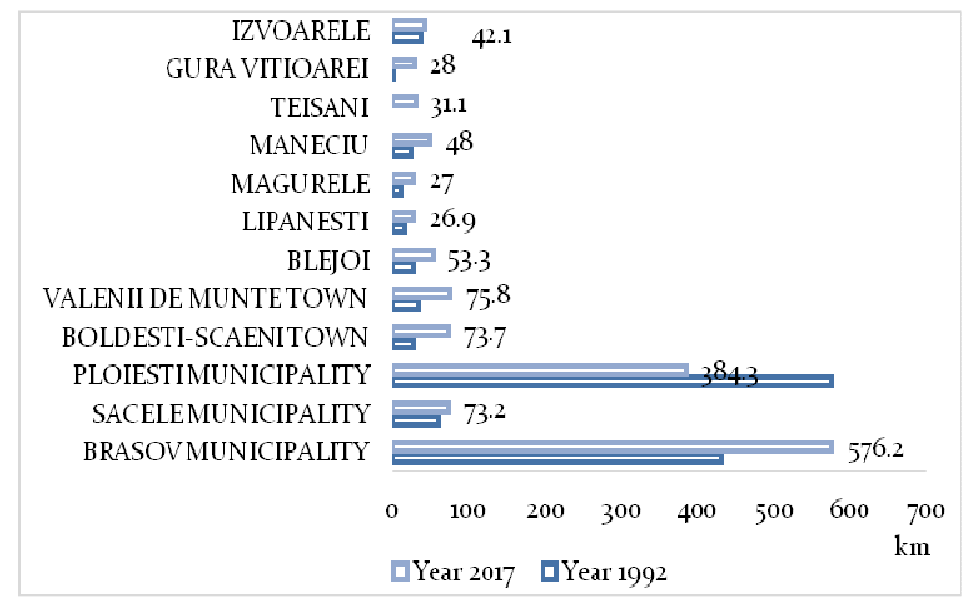

Fig. 10. Total length of potable water network for the towns analysed (1992-2017) Source of data: INS, tempo on line data base

The company APA BRAŞOV is directly responsible for the monitoring, treatment, distribution of potable water, but also the evacuation of household and industrial wastewaters from the municipalities of Braşov and Săcele. In the Prahova side, the water storage tanks Măneciu and Paltinu are the surface sources in the supply with water of Ploiești municipality and the town Vălenii de Munte, which completes its necessity from underground sources. The town Boldeşti-Scăieni distributes water from the catchment of water Recea-Lipăneşti, and the villages (Gura Vitioarei, Măgurele, Teişani) distribute water from the public service of local councils or of economic agents (Blejoi, Izvoarele, Lipăneşti, Măneciu) (PATJ Prahova, 2002).

Out of the twelve towns from the area delimited by Ploieşti - Vălenii de Munte - Braşov Axis, three of them: Măneciu, Teişani and Izvoarele, do not have infrastructure for the supply with gases of households. It is worth mentioning that Gura Vitioarei commune has had a gas supply network since 1997. In general, the total length of gas distribution pipes has increased in the last twenty-five years gradually (Fig. 11). 


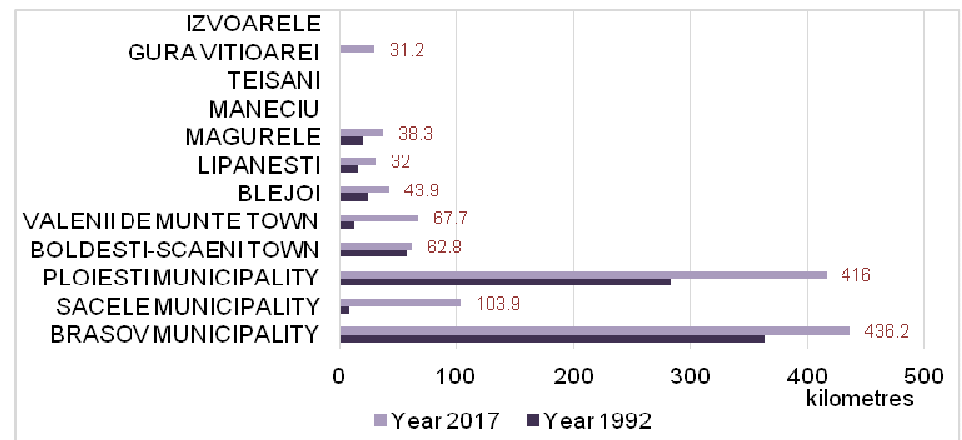

Fig. 11. Total length of natural gas distribution pipes for the towns analysed (1992-2017) Source of data: INS, tempo on line data base

The sewerage in Braşov Municipality arrives almost always in Timiş Channel and Timișul Sec Brook, and the wastewaters are treated in Stupini Treatment Plant, with a capacity of $1620 \mathrm{l} / \mathrm{s}$, with biological and mechanical treatment steps. The Municipality of Ploieşti has mixed sewerage system for wastewaters (the household wastewaters get to the treatment plants and the rainfall waters get to Dâmbu Brook), while in the town Boldești-Scăieni the sewerage of wastewaters is performed in separate sewage system and in the town Vălenii de Munte there is a unitary sewage system with treatment plant with mechanical and biological treatment steps. The wastewaters from the villages get to water treatment plants with mechanical treatment step. In the chart of Fig. 12, we can see the difficult territorial development because of the inability of local authorities to implement an adequate sewage network, with small projects in the communes Măneciu and Blejoi.

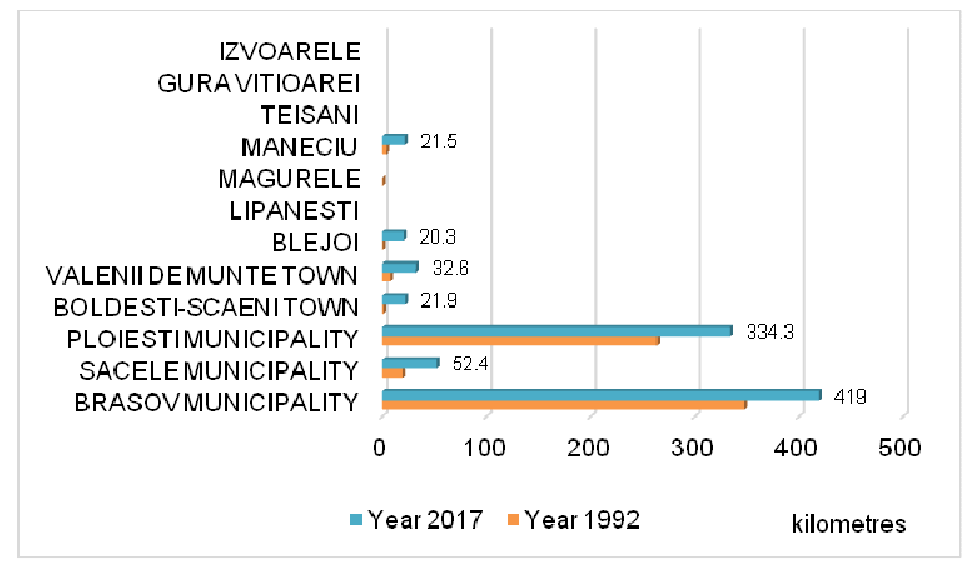

Fig. 12. Total simple length of sewerage pipes for the towns analysed (1992-2017) Source of data: INS, tempo on line data base 
S.C. Electrica Distribuţie Muntenia Nord is the company which provides electricity in the whole Prahova county by Ploiești Branch. Ploieşti Municipality has $221 \mathrm{~km}$ of public lighting grid (ISUPh, 2013). The district heating plant of Brașov municipality provides both electric and thermal energy to the whole city, but the supply and management are handled by S.C. Electrica Distribuţie Transilvania Sud (SDDJBV, 2010). Săcele Municipality procures the necessity of electricity from the National Energy System, but there are problems, because of city expansion the network has been overloaded. Moreover, in Gârcini district, underprivileged area of the town Săcele, constructions without authorisations have appeared (against the background of demographic growth) for the population without income who did not connect to the electricity grid or even worse, connected illegally to the electricity grid (SDD Săcele, 2014).

The municipal wastes are compacted by the public sanitation services which collect them from the whole Brassov county, with small exceptions in certain areas of the towns (for example: Gârnici district from Săcele municipality). The landfill of Rupea had a closure deadline in July 2017 (nonconforming activity), the landfill of Braşov area (collects the wastes from the south-eastern side of the omonym county), these are the authorised areas for storage of wastes in Brașov county; the building of a landfill in Făgăraş area has also been planned (SDDJBV, 2010). Fin-Eco is the company which manages the ecological ramp from the edge of municipality, which finished the third storage cell of residues so that Braşov will have safe landfills for wastes for five years (http://fineco.ro/rampa-ecologica-brasov, 2018). Prahova County is a leader in the adequate management of wastes (only 3 towns do not have sanitation services (PDDJ Prahova, 2013)), there are ecological ramps in area in: Boldeşti-Scăieni (which serves the towns from the southern half of the county), Vălenii de Munte (collects wastes from the north-eastern part of the county) etc.

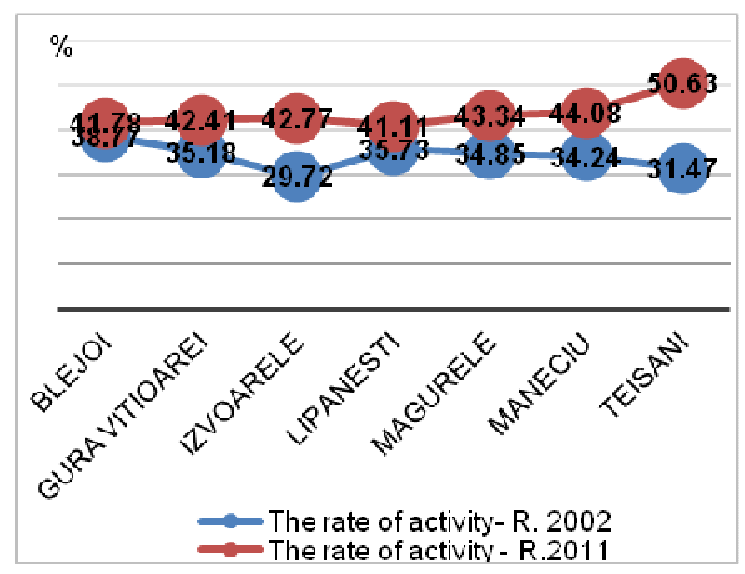

Fig. 13. Activity rate in the censuses of 2002 and 2011 for the seven rural settlements 
The activity rate has slightly increased during a decade, in each village (Fig. 13). Significant increases were recorded in Teișani Commune against the background of growth of occupied population (dramatic fall of unemployment rate to $6.3 \%$ in 2011 from $28.9 \%$ in 2002 ).

\section{Single specialisation of villages}

Commune is the basic administrative form in Romania and includes one or more villages ("residence centre (...) centre of material production in a welldetermined regional frame" (351 law, 2001). The rural settlements "have evolved in close connection with the productive potential of the land, with agricultural techniques, later with specialisation in crafts and industrial activities" (Cândea, Bogan, \& Simion, 2011). The area delimited by Ploieşti - Vălenii de Munte - Braşov Axis contains: villages with mainly tourist activities (Suzana Convent and Cheia Monastery are components of Măneciu commune), agro-industrial rural settelement (Teișani), agroindustrial and services settlements (Blejoi, Izvoarele, MăneciuUngureni, Lipănești) and mainly rural agricultural settlements (Măgurele, Gura Vitioarei). At the 2011 census, it has been noted that the agriculture workers have increased in number compared to the number of those from industry and commerce which recorded slight decreases, in the seven rural localities analysed.

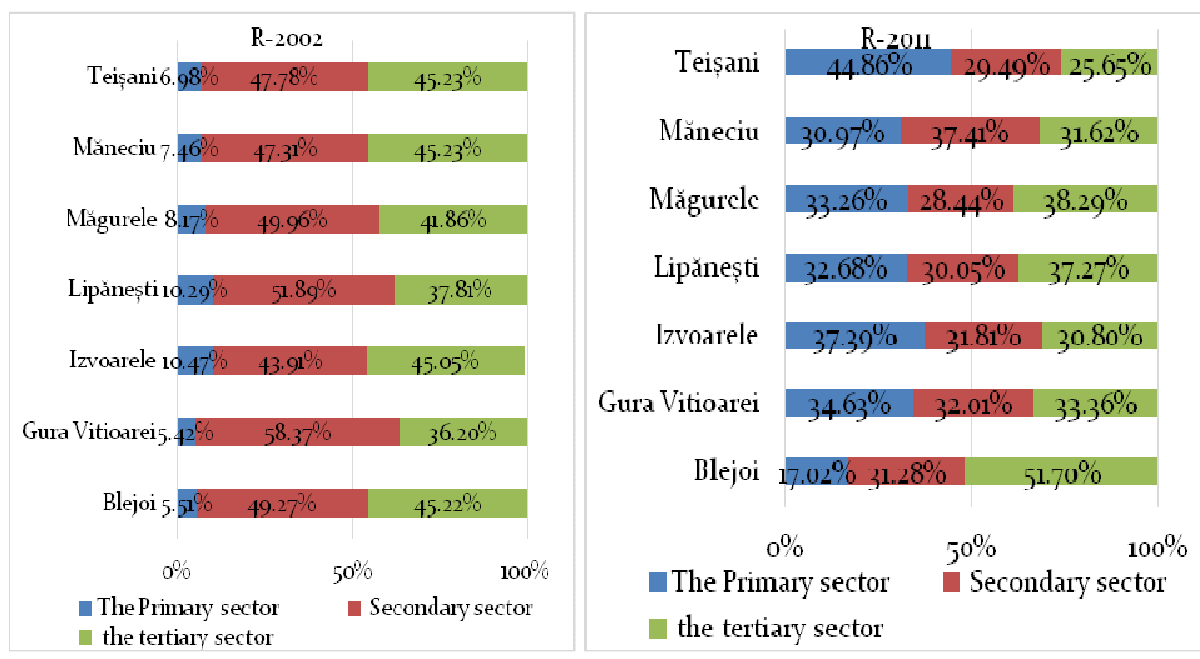

Fig. 14. Occupied population by sectors of activity in the seven communes for the censuses of 2002 and 2011 by comparison

Also, the tertiary sector has suffered slight changes in the communes Teişani, Măneciu, Izvoarele, Măgurele, slight decreases in favour of the primary sector, 
due to the return of population to the basic activities (animal breeding, agriculture, pomiculture) (Fig.14). Spectacular growth was recorded since 2002 until 2011 in the tertiary sector in the commune Blejoi, adjacent to Ploiești municipality, from $45 \%$ to $51 \%$. However, we can see the specialisation of each town: Blejoi - industry and commerce progressed, because of close vicinity to the city, while in the areas far from the city (Izvoarele şi Măneciu, Teişani) agriculture plays an important part.

\section{Conclusions}

Ploieşti - Vălenii de Munte - Braşov Axis has represented a link between two Romanian regions since the ancient times and can be valorised in tourism.

The territorial cohesion is the most discussed social topic, for which reason the dysfunctions that exist in the areas delimited by axis require solutions. There are significant problems with the urban technical infrastructure, the sewerage network is not present in all the analysed communes, the collection of wastes is not complete, the gas and water pipes do not get to all households, time and involvement in the sustainable development are necessary.

The widening of National Road 1A to two lanes by each direction, investments in tourist infrastructure by diversification of tourist attractions and transformation of the area from transit area to recreational area, hitchhiking and entertainment are only just a few imperious measures, along with the correlation of natural potential to the social potential, by revitalization of urban centres with history, Vălenii de Munte and Boldeşti-Scăieni, revitalization of traditional villages. The improvement of secondary urban centres and the realization of sustainable urban-rural partnerships is just one of the specific policies of European Union, when we analyse the polycentricity concept.

\section{Acknowledgements}

I would like to express my special thanks of gratitude to the employees of the information dissemination department from the National Institute of Statistics and the Statistics Division of Prahova County, for their professionalism and promptness. I am also grateful to Professor Tălângă Cristian for his encouragement and coordination of steps in my research.

\section{BIBLIOGRAPHY}

Bocioacă I. 2004, Vălenii de Munte, Editura ASA, București.

Bocioacă, I., Popescu, P., 1988, Vălenii de Munte. A great place to settle, Editura Sport-Turism, București. 
Cândea, M., Bogan, E., Simion, T., 2011. Human settlements and Organisation of Romanian Geographic Space Course Notes Bucharest: Editura Universitară.

Cruceru, A., 2011, Teleajenului Valley in old cartographic matters. Introduction to the study of settlements. Milcovia - regional magazine of studies, 3rd Series, year VII, no. 12, 54-57.

Erdeli, G., Dumitrache, L., 2001, Geography of population. Corint Publishing House, Bucharest.

Ielenicz, M., Pătru, Ileana Georgeta, Ghincea, Mioara, 2003, Subcarpathians of Romania, Universitară Publishing House, Bucharest.

Niculescu, Gh., Velcea, I., 1973, Prahova County, Editura Academia Republica Socialista Romania, Bucharest.

Nae, M., 2006, Geografia calităţii vieţii urbane - Metode de analiză (Geography of quality of urban life - Analysis Methods), Editura Universitară, Bucharest.

Peptenatu, D., Pintilii, R., Cepoiu, Loreta, Drăghici, C., 2009, 'Polycentric development strategy - an efficient instrument in administrative descentralization', Revista Română de Geografie Politică, An XI, vol. 2, pp. 99-111.

Petrescu, C.I., 2006, MihaiViteazul and the art of diplomacy, Editura Premier, Ploiești.

Pintilii, R., 2009, 'Structural axes and poles within the Buchares influence area', Human Geographies, vol. 2, nr. 1, pp. 69-81.

*** (1983) European Territory Arrangement Charter. European Territory Arrangement Charter, Strategy for sustainable transportation for the period 2007-2013 and 2020, 2030. European Conference of Ministers Responsible for Territory Arrangement. Spain: Council of Europe.

*** (2013) ISUPh. Plan of Analysis and Risks Coverage of Prahova County $-6^{\text {th }}$ edition. Retrieved from http://www.isuprahova.ro/pdf/sthp/PAAR_2016.pdf

*** (2002) Local Agenda 21 - Sustainable Development Strategy of Ploiesti Municipality, Ploiești.

*** (2002, December). PATJ Prahova. The Territorial Arrangement Plan of Prahova County. Retrieved from http://www.mdrap.ro/_documente/dezvoltare_teritoriala/amenajarea_terito riului/patj_prahova/patj_prahova_memoriu1.pdf ; http://www.mdrap.ro/_documente/dezv oltare_teritoriala/amenajarea_teritoriului/patj_prahova/patj_prahova_memoriu1.pdf

*** (2007, April 19) Law no. 100. LAW no. 100 of 19 April 2007 for the amendment and supplementation of Law no. 351/2001 for approval of National Territory Arrangement Plan - Section IV - Network of towns. Retrieved from https://lege5.ro/Gratuit/geydmobrgi /legea-nr-100-2007-pentru-modificarea-si-completarea-legii-nr-351-2001-privind-aprobar ea-planului-de-amenajare-a-teritoriului-national-sectiunea-a-iv-a-reteaua-de-localitati

*** (2001, July 6). Law no. 351. (Law no. 351 of 2001 for approval of National Territory Arrangement Plan - Section IV - Network of Towns Retrieved from Legea 351 din 2001 privind probarea Planului de amenajare a teritoriului naţional - Secţiunea a IV-a - Reţeaua de Localităţi: https://lege5.ro/.../legea-nr-351-2001-privind-aprobarea-planului-de-amenajare-a-terit...

*** (2007, may) LEIPYIG CHARTA on Sustainable European Cities Retrieved from https://ec.europa.eu/regional_policy/archive/themes/urban/leipzig_charter.pdf

*** (2009) PATN Section VI - Tourist areas, National Territory Arrangement Plan - Section VI - Tourist Areas Romania.

*** (2013, November) PDDJ Prahova. The Sustainable Development Plan of Prahova County for the period 2014-2020. Retrieved from http://www.cjph.ro/files/Documente/Strategiiprograme/Plan-de-dezvoltare-durabila-2014-2020-iunie-2016-cu-anexe.pdf

*** (2008) PUG Lipăneşti. General Memorium. Updating of General Urban Plan for Lipănești Commune, Prahova county.

*** (2010, November) SDDJBV. Sustainable Development Strategy of Brașov County Orizonturile 2013-2020-2030. Retrieved from https://addjb.ro/uploads/proiecte/SDJBV/D ocumente/ADDJB_Strategia.pdf

*** (2014) SDD Gura Vitioarei Local sustainable development strategy of the commons Gura Vitioarei 2014-2020, Retrieved from http://guravitioarei.ro/images/Dezvoltare/gura-vitio arei-CAP-123.pdf 
*** (2014, October) SDD Săcele. Sustainable Development Strategy of Săcele Municipality 2014-2020. Retrieved from https://addjb.ro/.../SACELE_MUNICIPIU/.../strategie_dezvolt are_sacele_2014_2020...

*** (2015) SDL Magurele Local development strategy of the common Magurele, Retrieved from https://www.magurele-ph.ro/atasamente/documente/251/Strategia\%20de\%20Dezvo ltare\%20Locala\%20a\%20\%20comunei\%20Magurele $\% 202015 \% 20 \% 20 \% 202020, \% 20$ jud etul\%20Prahova.pdf

*** (2014) SDTR. Territorial Development Strategy of Romania - Polycentric Romania 2035 Cohesion and Territorial Competitiveness, Development and Equal Chances for People. Version 2. Retrieved from Strategia de Dezvoltare Teritorială a României - Romania policentrică 2035 - Coeziune şi competitivitate teritorială, dezvoltare şi şanse egale pentru oameni. Version 2.

*** (2008) Sustainable Transportation Strategy. Sustainable Transportation Strategy for the period 2007-2013 and 2020, 2030.

National Institute of Statistics (2018, November 21). Retrieved from http://statistici.insse.ro/s hop/index.jsp?page $=$ tempo3\&lang $=$ ro\&ind $=$ POP107A

*** (2018, November) Transferoviar Călători. Retrieved from https://www.transferoviarcalatori.ro/

http://www.brasovcity.ro/index.php?ck=17. (2016, februarie 19). Retrieved from ttp://www.br asovcity.ro/index.php?ck=17

www.ploiesti.ro. (2016, January 20). Retrieved from www.ploiesti.ro

http://fin-eco.ro/rampa-ecologica-brasov. (2018, November 20). Retrieved from http://fin-eco.r o/rampa-ecologica-brasov, 20.11.2018

http://www.brasov.insse.ro/main.php?id=406. (2015). Retrieved from http://www.brasov.insse.ro /main.php?id=406

http://www.carpati.org. (2016, Februarie 2). Retrieved from http://www.carpati.org/articol/valea _teleajenului-o_picatura_de_geografie_o_picatura_de_istorie_2_/657/

http://www.prahova.insse.ro/main.php?id=434. (2015). Retrieved from http://www.prahova.in sse.ro/main.php?id=434 